\title{
UPAYA MENGURANGI KELELAHAN DALAM UJI KOMPETENSI KEAHLIAN OTOMOTIF DI SEKOLAH MENENGAH KEJURUAN DENGAN UJI MODEL TIDAK KONTINYU
}

\section{EFFORTS TO REDUCE FATIGUE IN THE AUTOMOTIVE SKILL COMPETENCE TEST IN VOCATIONAL SCHOOL USING DISCONTINUE TEST MODEL}

\author{
Abdurrahman \\ Universitas Negeri Semarang \\ Kampus Sekaran Gunungpati Semarang 50229 \\ e-mail: abdurrahman_unnes@yahoo.co.id
}

Naskah diterima tanggal: 14/03/2014, Direvisi akhir tanggal: 04/04/2015, Disetujui tanggal: 05/04/2015

\begin{abstract}
The purpose of this study is intended to find strategies for the atmosphere tense of the test will not be frightening and find a model of competency test management that can reduce students' fatigue. This study uses the Research and Development approach. The study begins from the preliminary study was followed by focus groups or focus group discussion in order to improve the model. Completion of the model begins with the refinement of model I to model II, and is terminated by validation of the model II by experts and practitioners about the feasibility of the model. There are two products in this study, they are 1) assessment manual of to be fun assessors, and 2) the discontinue model competence test. The results of the research show that of the 10 assessors models, four assessors state highly appropriate, four assessors state very appropriate, and two assessors state appropriate. Based on the assessments, the model of the study is very feasible to apply. The conclusion of the research concluded that the factors of calmness and fearlessness in doing tasks for students need to be confirmed, because these factors are really helpful to them. Students should have a break right after finishing at ask that they wil not become tired.
\end{abstract}

Keywords: fatigue, competence test, discontinue model of competency test.

\begin{abstract}
Abstrak: Penelitian ini bertujuan menemukan strategi bagaimana suasana ujian tidak mencekam dan menemukan model manajemen pelaksanaan uji kompetensi yang dapat mengurangi kelelahan siswa. Penelitian ini menggunakan pendekatan research and development. Penelitian diawali dengan penelitian pendahuluan dan dilanjutkan dengan diskusi kelompok terarah atau focus group discussion untuk penyempurnan model. Penyempurnaan model diawali dengan perbaikan model I menjadi model II, dan diakhiri dengan validasi model II oleh para pakar dan praktisi. Terdapat dua produk dalam penelitian ini, yaitu: 1) Panduan penilaian menjadi asesor yang menyenangkan dan 2) Uji kompetensi model tidak kontinyu. Hasil penelitian menunjukkan bahwa dari 10 penilai model, empat orang penilai menyatakan sangat layak sekali, empat orang penilai menyatakan sangat layak, dan dua orang penilai menyatakan layak. Berdasarkan penilaian tersebut dapat disimpulkan bahwa model temuan penelitian ini sangat layak diterapkan di SMK. Faktor ketenangan siswa dan bebas dari rasa takut dalam mengerjakan uji kompetensi perlu diperhatikan, dengan cara siswa perlu diberi jeda istirahat setelah selesai mengerjakan satu tugas.
\end{abstract}

Kata kunci: kelelahan siswa, uji kompetensi, model uji kompetensi tidak kontinyu 


\section{Pendahuluan}

Undang Undang Republik Indonesia Nomor 20 Tahun 2003, tentang Sistem Pendidikan Nasional Bab II Pasal 3, menyebutkan bahwa salah satu tujuan didirikan sekolah menengah kejuruan (SMK) yaitu membekali peserta didik dengan kompetensi yang dibutuhkan untuk bekerja. Selanjutnya, disebutkan bahwa tingkat pekerjaan bagi lulusan SMK adalah untuk mengisi lowongan pekerjaan yang ada di dunia usaha dan dunia industri (DUDI) sebagai tenaga kerja tingkat menengah.

Direktur Pembinaan SMK, Anang Tjahjono dalam Kata Pengantarnya mengatakan Uji Kompetensi Keahlian pada SMK merupakan bagian Ujian Nasional. Hasil uji kompetensi menjadi indikator ketercapaian standar kompetensi lulusan yang tertuang dalam Permendiknas Nomor 28 Tahun 2009, sedangkan bagi stakeholder akan dijadikan sebagai informasi atas kompetensi yang dimiliki si calon tenaga kerja (Direktorat Pembinaan Sekolah Menengah Kejuruan. 2013).

Berdasarkan data dari Lembaga Sertifikat Profesi (LSP) Jakarta (2010), pada periode Januari sampai Juni tahun 2010 jumlah peserta uji kompetensi bidang keahlian otomotif di Tempat Uji Kompetensi (TUK) yang tersebar di seluruh Indonesia sebanyak 1410 orang peserta. Dari jumlah peserta tersebut yang dinyatakan lulus/ kompeten sebanyak 1125 orang dan yang tidak lulus sebanyak 285 peserta $(20,21 \%)$. Data tersebut menunjukkan bahwa demikian sulitnya untuk mendapatkan sertifikat kompetensi yang diselenggarakan oleh LSP.

Di Indonesia saat ini terdapat 70 Tempat Uji Kompetensi (TUK) bidang keahlian otomotif. Khusus Jawa Tengah memiliki 29 TUK. Berdasarkan informasi dari Asesor Master LSP Otomotif, sampai dengan pertengahan tahun 2011 terdapat 2 TUK yang berada di Jawa Tengah, yaitu TUK SMK Ma'arif Kudus dan TUK SMKN 1 Semarang. Siswa yang pernah mengikuti uji kompetensi di TUK SMK Ma'arif sebanyak 280, jumlah peserta yang gagal 42, dan siswa yang uji kompetensi di TUK SMKN1 Semarang sebanyak 32 yang gagal 10. Dari 2 SMK tersebut jika dihitung jumlah peserta yang gagal sebanyak 52 orang peserta $(14,2 \%)$.

Fenomena ini memunculkan gagasan baru bahwa siswa SMK tidak harus mengikuti uji kompetensi versi LSP, tetapi bisa mengikuti uji kompetensi sesuai peraturan dinas pendidikan setempat, yaitu uji kompetensi yang diselenggarakan atas kerjasama antara SMK dengan dunia usaha dan dunia industri (DUDI).

Secara ekplisit Direktur Pembinaan SMK pada tanggal 09 April 2007 mengirim Surat Edaran kepada Kepala Dinas Pendidikan Provinsi/ Kabupaten/Kota seluruh Indonesia mempertegas dan menindaklanjuti Surat Edaran Dirjen Mendikdasmen Depdiknas Nomor 351/C.C5/MN/ 2007 tanggal 26 Januari 2007 perihal Pelaksanaan Uji Kompetensi Keahlian SMK pada Tahun Pelajaran 2006/2007. Peraturan dimaksud memuat hal-hal berikut: 1) dalam rangka pelaksanaan Uji Kompetensi Keahlian pada Ujian Nasional Tahun Pelajaran 2006/2007 tidak ada keharusan bagi siswa untuk mengikuti uji dan sertifikasi kompetensi yang diselenggarakan oleh Lembaga Sertifikasi Profesi (LSP); 2) keikutsertaan siswa pada uji dan sertifikasi kompetensi melalui LSP, tidak menentukan kelulusan siswa pada mata uji kompetensi keahlian sebagai bagian dari Ujian Nasional SMK Tahun Pelajaran 2006/2007. Karena informasi tersebut di atas merupakan hal yang sangat penting dan mendesak, Direktur Pembinaan SMK mengharapkan agar segera disosialisasikan ke SMK di wilayah masing-masing. Surat Edaran ini menjadi dasar bagi SMK untuk mengadakan uji kompetensi berkolaborasi dengan DUDI.

Hasil Penelitian Samsudi, Budiyono, Supraptono, Wijaya, dan Widayat (2007) menemukan bahwa penyelenggaraan uji kompetensi siswa SMK menunjukkan bahwa: 1) $50.33 \%$ sekolah berkolaborasi dengan DUDI; 2) $26.04 \%$ sekolah berkolaborasi dengan asosiasi profesi; 3) $18.72 \%$ UKK diselenggarakan oleh sekolah sepenuhnya; 4) $17.33 \%$ sekolah berkolaborasi dengan LSP; dan 5) $1.84 \%$ sekolah melaksanakan dengan model lain yaitu 
penyelenggaraan uji kompetensi dilakukan dengan Balai Latihan dan Pendidikan Tehnik (BLPT) di Palembang, Sumatera Selatan.

Direktur Pembinaan SMK memberi kebebasan kepada sekolah untuk memilih salah satu dari lima pilihan tersebut. Pemberian kebebasan ini didasari atas pertimbangan bahwa di Indonesia kondisi sekolah kejuruan sangat beragam terutama fasilitas peralatan praktik, kualifikasi guru, daya dukung DUDI di sekitar sekolah, dan kemampuan ekonomi orang tua siswa. Hasil penelitian tersebut menunjukkan bahwa yang paling banyak diterapkan oleh SMK yaitu uji kompetensi sekolah kolaborasi dengan DUDI. Model penyelenggaraan uji kompetensi kerja sama sekolah dengan DUDI, asesornya berasal dari sekolah dan DUDI dan sertifikatnya dikeluarkan oleh DUDI.

Banyak permasalahan yang muncul dalam pelaksanaan uji kompetensi terkait dengan standar pelaksanaan yang ditetapkan oleh pemerintah. Dari aspek asesor telah ditentukan, bahwa seorang asesi harus dinilai oleh asesor internal dan asesor ekternal yang skornya diambil rerata sebagai acuan untuk menentukan lulus tidaknya asesi. Kenyataan yang terjadi jumlah asesor ekternal yang dikirim ke sekolah hanya satu atau maksimal dua asesor, sehingga mereka hanya menguji beberapa siswa. Siswa yang lain diuji oleh dua asesor internal. Hal ini yang menjadi salah satu penyebab pemegang sertifikat tidak diakui oleh DUDI. Permasalahan lain yang umum dialami oleh sekolah adalah fasilitas peralatan uji yang masih konvensional. Harapan DUDI belum terpenuhi karena di bengkel kondisi teknologi otomotif sudah banyak yang hi-tech.

Dalam rangka menyeragamkan materi uji di seluruh Indonesia, Direktorat Pembina SMK menyediakan paket soal yang terdiri dari lima materi uji setiap paketnya. Sekolah bisa memilih salah satu paket dari lima paket yang ada. Pemilihan paket oleh sekolah didasarkan atas kesiapan fasilitas yang dimiliki oleh sekolah. Pelaksanaan uji kompetensi dilaksanakan secara kontinyu, yaitu beruntun dari pos 1 ke pos 2 dan seterusnya hingga pos 5, lihat Gambar 1. Peserta selama 5 jam mengerjakan tugas secara terus-menerus (kontinyu).

Model kontinyu melelahkan siswa, karena selama 5 jam mereka mengerjakan tugas dari tugas 1 sampai tugas 5. Mekanismenya sebagai berikut: siswa A mengerjakan Kopling, siswa B mengerjakan Transmisi, siswa $\mathrm{C}$ mengerjakan Sistem Penerangan, siswa D mengerjakan Motor Stater, dan siswa E mengerjakan Tune up. Setelah 1 jam mengerjakan satu tugas, mereka berotasi mengerjakan tugas berikutnya. Demikian seterusnya, sampai 5 pekerjaan selesai. Kecuali lelah secara fisik mereka juga lelah secara psikis karena suasana uji yang mencekam, sikap asesor yang kurang ramah cenderung sering menambah ketakutan dan suasana uji menjadi tegang. Hal ini dapat berdampak pada perolehan skor, yaitu tidak bisa optimal. Oleh karena itu, solusi penyelesaian perlu segera ditemukan.

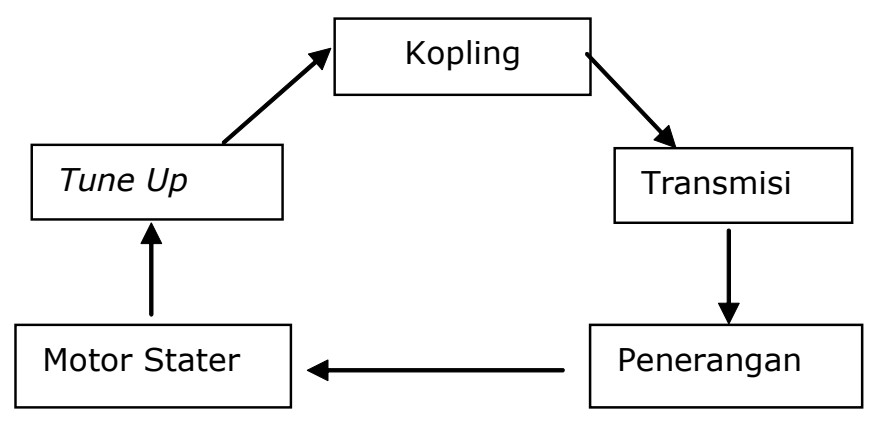

Sumber: Hasil observasi pelaksanaan uji kompetensi di SMK kota Semarang.

Gambar 1 Rotasi Uji Kompetensi Model Uji Kompetensi Kontinyu 
Masalah-masalah tersebut harus segera diselesaikan agar uji kompetensi di SMK tidak semakin terpuruk yang berakibat kualitas lulusannya menurun. Sehubungan dengan hal tersebut pada tahap awal salah satu komponen dalam proses pelaksanaan uji kompetensi perlu diperbaiki agar siswa optimal hasilnya, yaitu permasalahan yang terkait dengan menghindari faktor kelelahan fisik dan psikis siswa.

Berdasarkan latar belakang pemikiran tersebut, maka dirumuskan permasalahan sebagai berikut: 1) Bagaimana agar suasana uji kompetensi tidak mencekam? dan 2) Bagaimana model yang tepat dalam pelaksanaan uji kompetensi sehingga mampu mengurangi tingkat kelelahan siswa?

Mengacu pada rumusan masalah maka tujuan penelitian ini, yaitu: 1) Menemukan metode agar suasana ujian tidak mencekam, dan 2) Menemukan model manajemen pelaksanaan uji kompetensi yang dapat mengurangi kelelahan siswa.

\section{Kajian Literatur \\ Pendidikan Kejuruan}

Menurut Undang Undang Republik Indonesia Nomor 20 Tahun 2003 tentang Sistem Pendidikan Nasional "Pendidikan Menengah Kejuruan merupakan Pendidikan yang mempersiapkan peserta didik untuk dapat bekerja dalam bidang tertentu", sedangkan menurut Peraturan Pemerintah Republik Indonesia Nomor 19 tahun 2005 tentang Standar Nasional Pendidikan Pasal 26 ayat (3) dinyatakan bahwa "Standard kompetensi lulusan pada satuan pendidikan menengah kejuruan bertujuan untuk meningkatkan kecerdasan, pengetahuan, kepribadian, akhlak mulia, serta keterampilan untuk hidup mandiri dan mengikuti pendidikan lanjut sesuai dengan kejuruannya". Menurut Lazerzon dan Grubb (1974) "vocational education was created to prepare students for specific jobs, but many argue that this focus on narrow training should change".
Pada prinsipnya pendidikan kejuruan memiliki tujuan utama mencetak lulusan agar siap memasuki lapangan kerja. Hal ini yang membedakan antara pendidikan kejuruan dengan pendidikan umum. Semua komponen di dalam sistem pendidikan kejuruan untuk mendukung agar hasil akhir lulusannya memiliki keterampilan sesuai kebutuhan pasar, memiliki keahlian dan keberanian berwirausaha, dan mampu meningkatkan kualitas hidup. Hal ini sejalan dengan pendapat pakar pendidikan kejuruan Prosser yang dikutip Syamwil (2010) yang mengemukakan bahwa konsep pendidikan untuk penghidupan (Education for Life), yaitu memandang bahwa pendidikan bertujuan mempersiapkan siswa untuk bertahan hidup, mengembangkan karir, bekerja, dan memperoleh penghasilan (earning money).

Finch, Curtis, dan Crunkilton (1979) juga mengingatkan bahwa pendidikan itu pada dasarnya education for life pada pendidikan yang bersifat umum dan education for earning a living pada pendidikan kejuruan. Pendidikan kejuruan adalah pendidikan untuk mendapatkan penghasilan untuk kehidupan.

Berkenaan dengan kesiapan lulusan memasuki lapangan kerja, sekolah harus menjalin kerjasama dengan dunia usaha/dunia industri (DUDI). DUDI merupakan kekuatan utama bagi pendidikan kejuruan dalam hal mendukung kualitas lulusan khususnya tentang kompetensi praktik. Tingkat pekerjaan bagi lulusan SMK yaitu untuk mengisi lowongan pekerjaan yang ada di DUDI sebagai tenaga kerja tingkat menengah.

\section{Kompetensi}

Kompetensi merupakan perpaduan antara keterampilan (skill), perilaku/sikap (attitude) dan pengetahuan (knowledge) yang majemuk yang dapat didemontrasikan oleh siswa di mana keterampilan, sikap, dan pengetahuan tersebut diperoleh dari konseptualisasi materi yang telah dipelajari dan bermakna dalam kehidupan. Menurut Ennis (2008) "A Competency is the 
capability of applying or using knowledge, skill, abilities, behavior, and personal characteristicts to successfully perform critical work tasks, specific functions, or operate in a given role or position".

Uji Kompetensi adalah proses penilaian baik teknis maupun nonteknis melalui pengumpulan bukti yang relevan untuk menentukan apakah seseorang kompeten atau belum kompeten pada suatu unit kompetensi atau kualifikasi tertentu. Dapat dikatakan bahwa dalam uji kompetensi substansinya bukanlah menguji tetapi mencari bukti apakah siswa yang di uji dapat menunjukkan kompetensi yang dimiliki. Pembuktian dalam uji kompetensi penilaiannya tidak hanya difokuskan pada hasil, tetapi bagaimana proses siswa mengerjakan tugas, misal ketepatan alat yang digunakan, sikap dalam bekerja, urutan mengerjakan tugas (Standard Operating Procedure) masuk dalam skor penilaian.

Sebelum diberlakukan uji kompetensi di SMK, siswa mengikuti ujian praktik yang dilaksanakan di SMK. Pada ujian praktik penguasaan keterampilan yang diujikan tidak menunjuk secara ekplisit spesifikasi keahlian apa yang diujikan. Siswa diuji praktik dengan lingkup makro tanpa menggunakan rujukan kebutuhan kompetensi di industri. Hal ini berbeda dengan uji kompetensi yang rujukannya jelas, yaitu kebutuhan kompetensi di industri.

Uji kompetensi yang dilakukan di SMK di kota Semarang hingga saat ini masih menuai masalah diantaranya yaitu pemegang sertifikat belum diakui oleh industri. Model manajemen uji kompetensi di SMK yang diteliti masih banyak kelemahan. Dari aspek asesor belum ada program peningkatan kualitas asesor. Dari aspek materi uji juga belum ada perencanaan peningkatan materi uji yang sesuai harapan DUDI. Pelaksanaan uji kompetensi juga belum memperhatikan kondisi kelelahan siswa, kondisi lingkungan uji, dan belum pernah melakukan penelitian permasalahan yang terkait dengan uji kompetensi. Gambar 2 menunjukkan Model Manajemen Uji Kompetensi di SMK Kota Semarang (Model Faktual).
Pada model faktual kolom proses uji kompetensi ada 14 komponen, yaitu A sampai $\mathrm{N}$ yang terlibat langsung di dalam uji kompetensi. Komponen A (jumlah asesor) masih kurang terutama asesor ekternal. Komponen B (wawasan asesor), khususnya asesor internal masih perlu observasi ke bengkel tempat siswa magang. Komponen C (dana), perlu dihitung kebutuhan dana yang diperlukan untuk uji kompetensi. D (ruang), ruang uji kompetensi kurang nyaman, masih banyak peralatan yang sudah tidak dipakai ada di dalam ruang praktik, E (alat konvensional), penyediaan alat untuk laboratorium otomotif di SMK sangat bervariasi. Ada yang sudah tertata rapi peralatan lengkap ada yang sebaliknya. F (materi uji), semua SMK belum melakukan uji trouble shooting. G (hitech), materi uji belum mengunakan materi hitech. H (asesor ekternal yang dikirim ke Unnes umumnya hanya 1), kondisi ini menyulitkan sekolah khususnya dalam memberikan nilai dari industri. I (asesor ekternal hanya hadir sabtu dan minggu), sulit bagi sekolah untuk merealisasi uji kompetensi sesuai peraturan. J (hanya sebagian kecil siswa diuji asesor ekternal), kondisi ini terealisasi di semua sekolah sejak diberlakukan uji kompetensi sebagai persyaratan lulus SMK. K (5 unsur manajemen skor di bawah 70), diperoleh dari pra survei hasil angket/ kuantitatif, yaitu unsur: Money, Machine, Directing, Reporting, Coordinating. L (kepuasan hasil uji), perlu ada pendekatan ke asesor agar asesor memberi selamat kepada siswa selesai uji. M (siswa lelah), proses uji kompetensi membutuhkan waktu istirahat. N (suasana mencekam), untuk mengatasi ini diperlukan peran asesor sebelum dan selama uji kompetensi.

Memperhatikan kelemahan pelaksanaan uji kompetensi, peneliti membuat rancangan model manajemen yang diharapkan dapat mengurangi kelemahan yang ada, khususnya faktor kelelahan siswa dari aspek fisik dan psikis.

Sebagai pembanding pola uji kompetensi, pada gambar 3 menjelaskan model sertifikasi untuk memperoleh tenaga kerja sesuai 


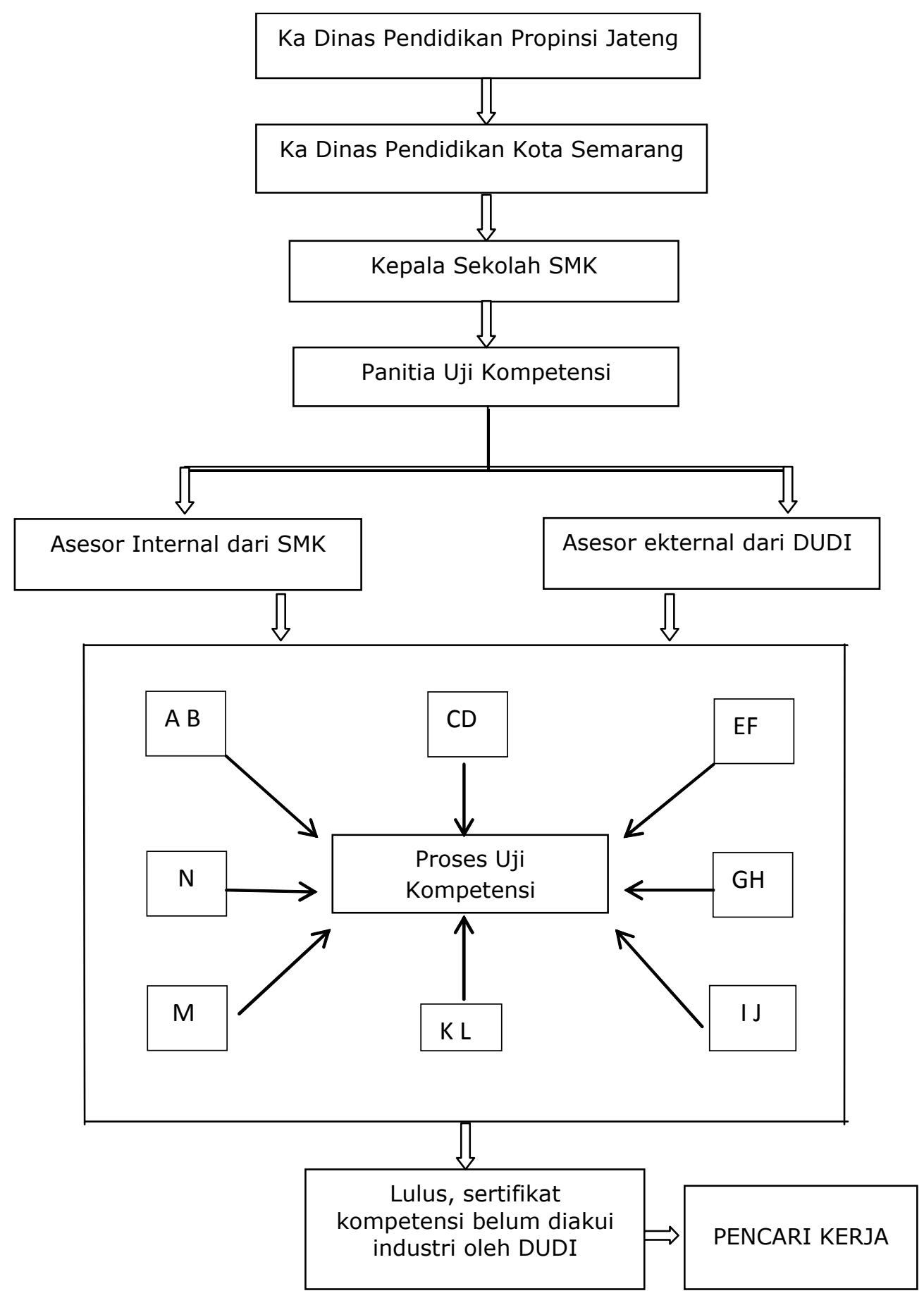

Gambar 2 Model Manajemen Uji Kompetensi di SMK Kota Semarang (Model Faktual)

kebutuhan industri. Langkah awal, yaitu menganalisis jenis keahlian yang dibutuhkan industri atau pasar kerja, kemudian dibuat standar baku yang minimal dimiliki oleh calon pekerja dan mengelompokkan ke dalam level (kualifikasi) keahlian. Kemudian dilanjutkan pengembangan instrumen penilaian dan bahan ajar, pelatihan, uji kompetensi, dan pemberian serifikat bagi yang kompeten. Proses tersebut merupakan salah satu proses sertifikasi yang rujukannya sudah pasti, yaitu kebutuhan industri. Uji kompetensi mengarah pada penguasaan keahlian tertentu yang dibutuhkan di industri sehingga pemegang sertifikat siap kerja sesuai jenis keahlian yang tertera pada sertifikat, sedangkan ujian praktik secara ekplisit 
materi uji tidak merujuk pada keahlian tertentu yang dibutuhkan di industri sehingga sulit bagi industri untuk mengakui keahliannya.

Ditinjau dari aspek obyektivitas penilaian, uji kompetensi memiliki tingkat obyektivitas yang tinggi karena penilaiannya berdasarkan hasil kinerja siswa tanpa mempertimbangkan hal-hal yang bersifat subyektif.

\section{Peran Asesor dalam Uji Kompetensi}

Asesor sebagai aktor dominan dalam menentukan kelulusan memiliki peran penting dalam uji kompetensi. Diharapkan siswa dapat mengikuti ujian dengan rasa aman sehingga siswa dapat mendemonstrasikan kompetensinya seoptimal mungkin.

Penelitian Subandowo (2009) tentang hubungan kelelahan nonfisik dengan produktivitas menyimpulkan bahwa faktor kelelahan non fisik hubungannya sangat kuat dengan produktivitas kerja. Hasil tersebut dikaitkan dengan suasana uji kompetensi dimungkinkan bahwa suasana mencekam siswa saat uji kompetensi dapat berpengaruh negatif terhadap prestasi uji kompetensi.

Panitia uji kompetensi harus dapat menciptakan suasana yang kondusif sehingga faktor non akademik tidak mengganggu faktor akademik yang mengakibatkan siswa tidak lulus. Zajonc pada tahun 1965 yang dikutip oleh Widyarni (2009) menemukan bahwa kinerja individu dihadapan orang lain akan meningkat bila individu itu terlatih. Sebaliknya, akan merosot bila kurang terlatih. Temuan tersebut memberi makna bahwa porsi latihan sebelum uji kompetensi sangat diperlukan, karena dihadapan penguji siswa yang kompetensinya kurang kemungkinan besar semakin gugup dan dampaknya adalah prestasinya menurun. Terkait dengan ketakutan dan kecemasan yang pada akhirnya menimbulkan stres, di dukung oleh penelitian yang dilakukan Halim sebagaimana dikutip oleh Kurniawati dan Astuti (2008) dengan menggunakan 76 sampel manajer dan mandor di perusahaan swasta di Jakarta menunjukkan bahwa efek stres yang mereka rasakan ada dua.
Dua hal tersebut yaitu: 1) Efek pada fisiologis mereka, seperti: jantung berdenyut kencang sehingga denyut jantung meningkat, bibir kering, berkeringat, mual dan 2) Efek pada psikologis mereka, di mana mereka merasa tegang, cemas, tidak bisa berkonsentrasi, ingin pergi ke kamar mandi, ingin meninggalkan situasi stres (artikelbaden, 2012).

\section{Model Pelaksanaan Uji Kompetensi}

Uji kompetensi yang diterapkan di SMK selama ini dilaksanakan secara kontinyu beruntun dari pos 1 (satu) ke pos 2 (dua) dan seterusnya sampai ke pos 5 (lima). Peserta selama 5 (lima) jam mengerjakan tugas sehingga melelahkan. Kelelahan dan mencekam selama uji kompetensi berdampak pada perolehan skor.

Siswa yang mengalami kelelahan fisik dan psikis saat mengerjakan uji kompetensi sudah dapat dipastikan hasilnya tidak optimal. Penelitian yang dilakukan oleh Muizzudin (2013) tentang Hubungan Antara Kelelahan Kerja Dengan Produktivitas Kerja PadaTenaga Kerja Bagian Tenun di PT. Alkatex Tegal, menyimpulkan bahwa ada hubungan antara kelelahan kerja dengan produktivitas kerja pada tenaga kerja bagian tenun di PT. Alkatex Tegal. Saran bagi pekerja bagian tenun di PT. Alkatex Tegal yaitu agar membiasakan diri untuk melakukan peregangan otot disela pekerjaan ataupun pada saat istirahat dan mempergunakan waktu istirahat yang diberikan dengan baik (artikelbaden.2012).

Gejala kelelahan kerja menurut Gilmer (1966) dan Cameron (1973) yang dikutip oleh Mauladi (2010) ditandai hal-hal sebagai berikut: a) Menurun kesiagaan dan perhatian; b) Penurunan dan hambatan persepsi; c) Cara berpikir atau perbuatan anti sosial; d) Tidak cocok dengan lingkungan; e) Depresi, kurang tenaga, dan kehilangan inisiatif; f) Gejala umum (sakit kepala, vertigo, gangguan fungsi paru dan jantung, kehilangan nafsu makan, gangguan pencemaan, kecemasan, perubahan tingkah laku, kegelisahan, dan kesukaran tidur). Sedangkan akibat Kelelahan Kerja adalah: a) 


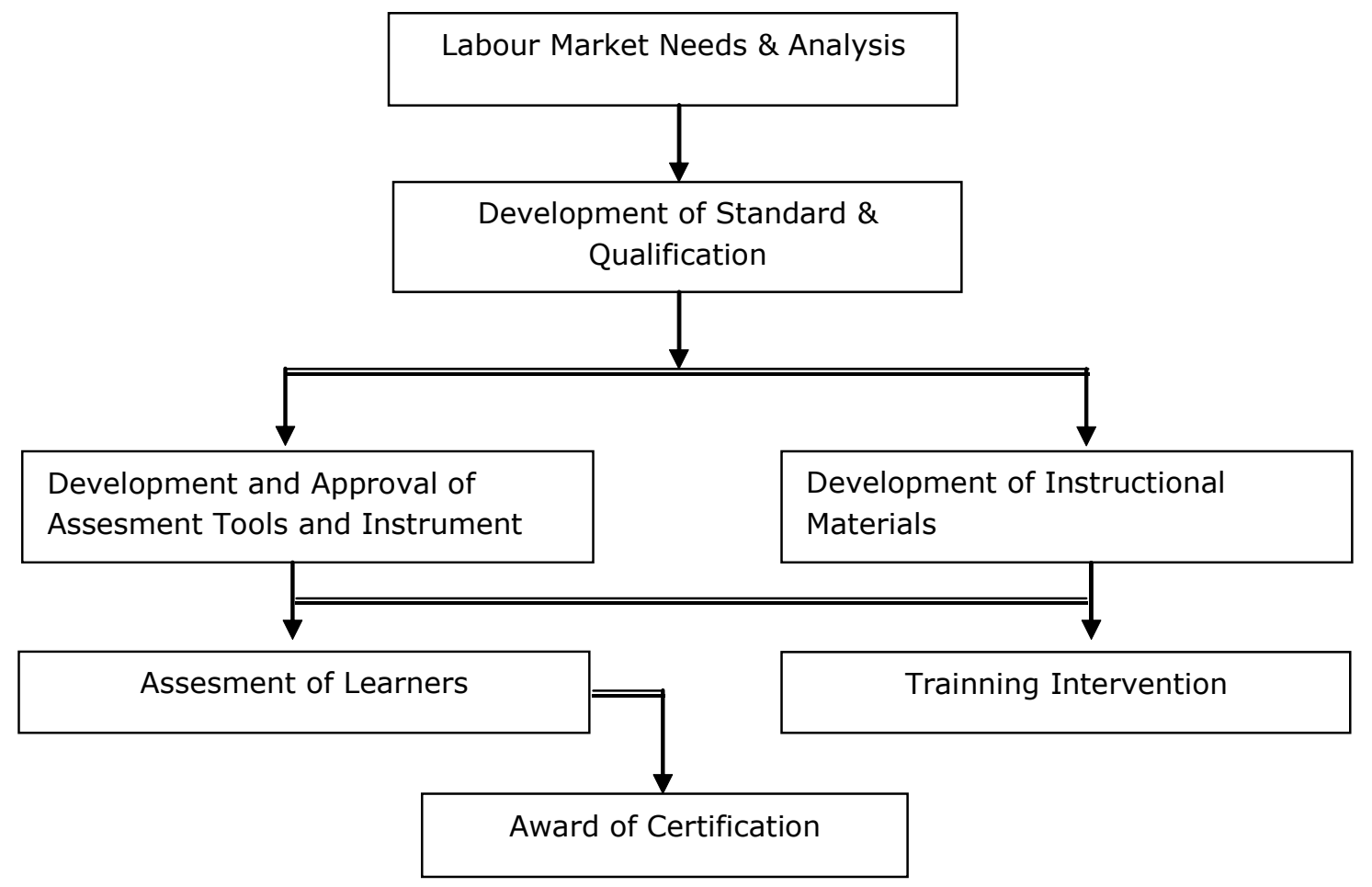

Sumber: Trinidad dan Tobago, 2005)

Gambar 3 Certification For Basic Labour Competition Model

Prestasi kerja yang menurun; b) Fungsi fisiologis motorik dan neural yang menurun; c) Badan terasa tidak enak; d) Semangat kerja yang menurun (Bartley dan Chute, 1982).

Demikian dampak negatif akibat kelelahan kerja bahkan bisa berakibat fatal. Oleh karena itu, perlu ada jeda waktu beristirahat saat melakukan kerja. Uji kompetensi yang berlangsung demikian lama (5 jam) cukup melelahkan, bahkan bagi siswa kegiatan uji kompetensi selama 5 (lima) jam di bawah pengawasan asesor merupakan beban yang tidak ringan. Kelelahan tidak hanya secara fisik, psikis juga terasa lelah. Kondisi ini tidak menguntungkan bagi siswa, karena akan berdampak perolehan skor uji kompetensi tidak optimal bahkan tidak lulus.

Dipandang perlu ada jeda untuk relaksasi setelah satu pekerjan selesai. Berapa lama istirahat yang sebaiknya dilakukan agar kondisi fisik kembali pulih? Menurut Murrel (1965) sebagaimana dikutip oleh Rochman, Astuti, dan Miftahudin (2012) merumuskan metoda untuk menentukan waktu istirahat sebagai kompensasi dari pekerjaan fisik sebagai berikut:

$$
\mathrm{R}=\frac{\mathrm{T}(\mathrm{W}-\mathrm{S})}{\mathrm{W}-1,5}
$$

$\mathrm{R}=$ Istirahat yang dibutuhkan dalam menit

$\mathrm{T}=$ Total waktu kerja dalam menit

$\mathrm{W}=$ Konsumsi energi rata-rata untuk bekerja dalam kkal/ menit?

$\mathrm{S}=$ Pengeluaran energi rata-rata yang direkomendasikan dalam kkal/min (biasanya 4 atau $5 \mathrm{kkal} /$ menit)

Besarnya W dapat dilihat pada Tabel 1 kolom Energi Ekspenditur.

Jika siswa yang sedang mengerja-kan tugas uji kompetensi dikategorikan ke dalam kerja berat, berarti mengeluarkan $8,5 \mathrm{Kkal} /$ menit (W), lama mengerjakan satu tugas 60 menit $(T)$, dan $\mathrm{S}=4 \mathrm{Kkal} /$ menit, maka: 


$$
\begin{aligned}
& R=\frac{60(8,5-4)}{8,5-1,5} \rightarrow \frac{60 \times 4,5}{7} \\
& R=\frac{270}{7} \rightarrow \quad R=38 \text { menit }
\end{aligned}
$$

Ini berarti setelah siswa mengerjakan satu pekerjan minimal beristirahat 38 menit. Dengan dasar pertimbangan bahwa mereka masih siswa yaitu fisik dan stamina belum sekuat mekanik di bengkel, jumlah materi uji 5 tugas, tiap tugas 60 menit, maka lama waktu istirahat dibuat 60 menit. Durasi istirahat dan uji setiap materi sama, yaitu 60 menit, sehingga pada waktu kelompok satu istirahat, alat uji dapat dipakai oleh kelompok dua demikian seterusnya sampai setiap siswa mengerjakan lima tugas.

Keuntungan dari durasi istirahat 60 menit adalah dalam satu hari satu set alat uji bisa dipergunakan untuk uji 10 siswa dalam waktu 10 jam. Jika durasi istirahat diambil 38 menit, selama 38 menit alat uji tidak bisa dipakai kelompok lain, sehingga dalam satu hari satu set alat uji hanya bisa dipakai untuk 5 siswa selama 7,5 jam. Keuntungan lain istirahat 60 menit, yaitu siswa bisa relaksasi dan membuat persiapan lebih leluasa.

\section{Metode Penelitian}

Penelitian ini dilakukan di kota Semarang dengan mengambil 6 sampel SMK, tiga SMK Negeri yaitu SMKN 1, SMKN 4, SMKN 5, dan tiga SMK swasta yaitu SMK Tlogosari, SMK Pelita Nusantara 2, dan SMK 17 Agustus 1945.

Penelitian ini menggunakan pendekatan Research and Development atau $R \& D$. Borg dan Gall (1983) menjelaskan bahwa "Educational research and development $(R \& D)$ is a process used to develop and validate educational products". Maksud dari R \& D adalah digunakan untuk mengembangkan dan memvalidasi produk pendidikan. Produk pendidikan menjadi tujuan utama yang merupakan hasil dari proses pengembangan produk yang telah digunakan sebelumnya.

Langkah-langkah penggunaan metode Research and Development (R\&D) oleh Borg \& Gall (1983), menguraikan ada 10 langkah umum dalam pendekatan penelitian dan pengembangan, yaitu: 1) Research and information collecting, 2) Planing, 3) Develop preliminary form of product, 4) Preliminary field testing, 5) Main product revision, 6) Main field testing, 7) Operational product revision, 8) Operational field testing, 9) Final product revision, 10) Dissemination and implementation. Dalam penelitian ini dibuat langkah-langkah yang lebih

Tabel 1 Klasifikasi Beban Kerja dan Reaksi Fisiologis

\begin{tabular}{ccccc}
\hline & \multicolumn{2}{c}{ Energi Ekspenditur } & Detak Jantung & $\begin{array}{c}\text { Konsumsi } \\
\text { Oksigen }\end{array}$ \\
\hline $\begin{array}{c}\text { Tingkat } \\
\text { Pekerjaan }\end{array}$ & Kkal / menit & Kkal / 8 jam & detak / menit & Liter/menit \\
\hline Unduly Heavy & $>12,5$ & $>6000$ & $>175$ & $>2.5$ \\
Very Heavy & $10-12,5$ & $4800-6000$ & $150-175$ & $2-2.5$ \\
Heavy & $7,5-10$ & $3600-4800$ & $125-150$ & $1.5-2$ \\
Moderate & $5-7,5$ & $2400-3600$ & $100-125$ & $1-1.5$ \\
Light & $2,5-5$ & $1200-2400$ & $60-100$ & $0.5-1$ \\
Very Light & $<2,5$ & $<1200$ & $<60$ & $<0.5$ \\
\hline
\end{tabular}

Sumber: Modul Pengukuran Performasi Kerja. http:// www.dhimaskasep.files.wordpress.com/2008/05/modul-2.doc 
detail seperti pada Gambar 4 , yang substansinya sama dengan pendapat Borg dan Gall (1983).

Penelitian ini tidak dilakukan lengkap sampai uji implementasi, tetapi berhenti pada Revisi Desain II. Alasan tidak dilakukanya hingga tahap uji implementasi karena temuan penelitian berupa model yang substansinya merupakan perubahan kebijakan. Melakukan uji coba model hasil penelitian ini akan menghentikan model lama yang selama ini dilakukan. Hal ini yang menjadi keberatan kepala sekolah, dikhawatirkan menggangu psikis siswa dalam uji kompetensi. Penelitian diakhiri sampai uji pakar dengan mengadakan penilaian terhadap model yang telah direvisi hasil FGD I. Uji pakar dilakukan dengan penilaian terhadap model dalam bentuk FGD II.

Kronologis penelitian sebagai berikut. Tahap I Studi Pendahuluan, dilaksanakan bulan Maret 2013. Pada tahap pendahuluan dilakukan studi literatur, pengamatan dan pengambilan data di lapangan, deskripsi data dan analisis kebutuhan yang faktual. Studi pendahuluan dilakukan di 6 SMK Negeri dan SMK Swasta yang menyelenggarakan Program Studi Keahlian Otomotif yang memiliki kompetensi keahlian Teknik Kendaraan Ringan (TKR).

Tahap II pembuatan model atas dasar studi pendahuluan dan literatur yang relevan.
Tahap III Focus Group Discussion (FGD) I dilaksanakan pada bulan Maret 2014. Tahap ini mendiskusikan model ke berbagai pihak terkait.

Tahap IV merevisi model. Hasil revisi dimintakan penilaian ke tim penilai dalam bentuk FGD II pada bulan September 2014. Tim penilai terdiri atas promotor, pakar manajemen, pakar pendidikan kejuruan, praktisi DUDI, Kepala Dinas Pendidikan dan Kebudayaan Kota Semarang, kepala sekolah, staf Lembaga Penjamin Mutu Pendidikan (LPMP) Jawa Tengah, dosen teknik mesin, dan Ikatan Teknisi Otomotif (ITO). Hasil penilaian tersebut dijadikan dasar layak tidaknya model untuk diimplementasikan/ diterapkan.

\section{Hasil Penelitian dan Pembahasan}

Uji kompetensi merupakan bagian dari Ujian Nasional (UN), secara ekplisit ditegaskan bahwa persyaratan untuk mengikuti UN, siswa harus lulus uji kompetensi. Persyaratan ini yang berdampak pada siswa menjadi tegang saat mengikuti uji kompetensi. Sering terjadi kegagalan uji kompetensi bukan karena siswa tidak mampu mengerjakan tugas, melainkan disebabkan rasa takut dan mencekam selama proses uji kompetensi, sehingga siswa tidak bisa kerja secara optimal. Oleh karena itu, perlu dicari solusi agar uji kompetensi bisa dikerjakan secara menyenangkan dan tidak mencekam. Salah satu

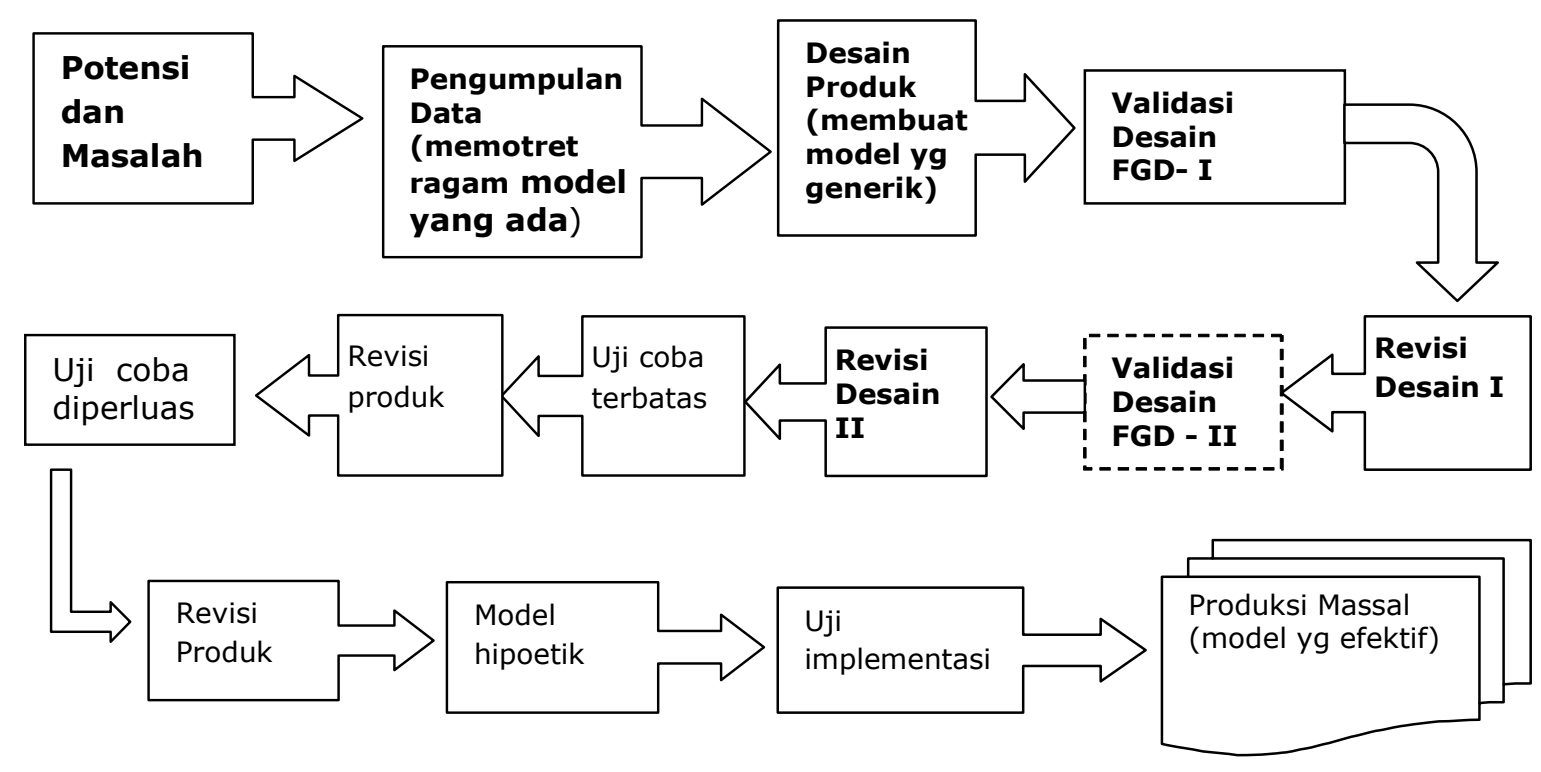

Gambar 4 Langkah-langkah Penggunaan Metode Research and Development 
upaya mengatasi hal tersebut yaitu membuat panduan asesor agar selama menguji dapat tercipta suasana yang menyenangkan.

\section{Panduan Asesor}

Salah satu produk dalam penelitian ini yaitu panduan penilaian "Menjadi asesor yang menyenangkan". Berikut isi sebagian panduan yang dibuat berdasarkan Indonesia Australia Partnership for Skill Development, Automotive Project (2001), beberapa istilah telah disesuaikan dengan kondisi disekolah.

\section{Kegiatan asesor sebelum uji kompetensi}

Uji kompetensi pada dasarnya merupakan unjuk kerja siswa yang oleh asesor dilakukan rekaman dalam wujud catatan bukti-bukti kompetensi siswa terhadap pekerjaan tertentu yang didemontrasikan di depan asesor. Asesor perlu menyampaikan informasi sebelum uji kompetensi dilakukan agar siswa memahami secara utuh hal-hal pokok yang terkait dengan uji kompetensi. Berikut ini hal-hal yang perlu disampaikan asesor kepada siswa, yaitu: 1) Tujuan penilaian; 2) Kondisi dimana penilaian akan dilaksanakan; 3) Prosedur-prosedur yang ada; 4) Penyusunan penilaian secara detail termasuk waktu, tempat, dan semua materi yang diperlukan untuk persedian (Indonesia Australia Partnership for Skill Development, Automotive Project, 2001).

\section{Kesalahan yang biasa dilakukan asesor ketika melakukan penilaian}

Asesor memiliki peran utama terhadap kualitas pemegang sertifikat kompetensi, karena asesor memiliki hak penuh menilai kompeten tidaknya siswa. Asesor sebaiknya tidak melakukan kesalahan yang mengakibatkan siswa tidak lulus. Berikut ini beberapa kesalahan yang sering dilakukan asesor sebagai berikut: 1) Kesan pertama, penilai sudah merasa suka atau tidak suka terhadap siswa. Selama penilaian si penilai akan dipengaruhi oleh kesan pertama tersebut, bukan standar unjuk kerja yang sebenaranya pada siswa tersebut; 2) Efek Cahaya, penilai membuat penilaian kepada siswa berdasarkan sikap-sikap terdahulu atau preferensi pribadi, bukan standar unjuk kerja siswa sebenarnya, misal penampilan peserta, gaya bicara, dan latar belakang; 3) Kesamaan dengan saya, penilai akan memberikan penilaian baik kepada siswa karena mereka merasa punya kesamaan karakteristik atau kebiasaan kerja dengan si penilai. Skenario sebaliknya juga dapat terjadi, "ketidaksamaan dengan saya" yang dapat mengarah pada penilaian yang kurang baik (subjektif) terhadap siswa; 4) Stereotipe/ Klise. Penilai menilai siswa berdasarkan karakteristik personal, bukan pada unjuk kerjanya (misalnya, jenis kelamin, suku, agama, dan umur); 5) Efek Kontras, penilaian dapat saja terpengaruh oleh kualitas (baik atau buruk) siswa sebelumnya; 6) Pengharapan, penilai tahu terlebih dahulu tentang siswa tersebut, misalnya mengetahui atau telah diberi tahu, akan dapat mengarah penilai pada harapan unjuk kerja yang tidak sesuai dari siswa. Contohnya, jika penilai berharap tinggi pada unjuk kerja siswa, penilai dapat menjadi sangat kritis pada unjuk kerja siswa dan hal ini sangat mempengaruhi penilaian; 7) "Efek Hawthorne", Kehadiran seorang penilai dapat mempengaruhi unjuk kerja siswa menjadi lebih baik maupun buruk. (Indonesia Australia Partnership for Skill Development, Automotive Project, 2001).

Ada dua kegiatan makro yang sebaiknya dilakukan oleh asesor, yaitu melibatkan siswa sebelum penilaian dan melibatkan siswa selama penilaian. Penilai harus bersikap supportive dan dapat meyakinkan siswa yang kelihatan gugup dan takut sebelum penilaian. Cara yang dapat dilakukan asesor sebelum penilaian, yaitu: a) Memastikan lingkungan sesuai untuk penilaian; b) Menciptakan atmosfir yang positif dan memperhatikan sekeliling; c) Meyakinkan siswa untuk tenang dan tidak takut; d) Memberi salam, menyambut siswa dan menciptakan hubungan baik (ingat untuk mengadakan kontak mata dan senyum); e) Memperbolehkan siswa untuk menenangkan diri dan merasa nyaman (sesekali membuat percakapan di luar 
penilaian); f) Berikan gambaran singkat tentang proses penilaian dengan cara yang mudah dimengerti (Indonesia Australia Partnership for Skil Development, Automotive Project, 2001).

Pada saat siswa diuji, pada umumnya merasa takut dan gugup dalam menjawab pertanyaan utamanya pertanyan yang harus dijawab secara lisan atau praktik mengerjakan suatu tugas. Ada beberapa cara untuk menetralisir agar dapat menunjukkan kompetensinya secara optimal. Berikut adalah sejumlah cara yang dapat dilakukan asesor selama penilaian, yaitu: a) Siswa harus merasa nyaman dengan proses penilaian dan yakin bahwa penilai akan bersikap adil ketika menilai kompetensi mereka; b) Penilai mengarahkan pertanyaan untuk pengumpulan informasi yang akan merupakan bukti kompetensi siswa; c) Memberi pertanyaan tertutup, yaitu pertanyaan yang jawabannya singkat "ya" atau "tidak"; d) Memberi pertanyaan terbuka, yaitu pertanyaan yang jawabannya bermacam-macam untuk menguraikan pendapat; e) Penilai harus memberikan semangat dan melibatkan si ternilai sebanyak mungkin untuk berpartisipasi dalam diskusi. Hindarkan pertanyaan yang mempunyai dua pengertian atau tidak jelas, yang pada akhirnya membingungkan dan membuat siswa tidak nyaman (Indonesia Australia Partnership for Skill, Development Automotive Project, 2001). Diharapkan dengan menerapkan panduan tersebut dapat membantu siswa menghilangkan rasa takut/stres selama mengikuti $u j i$ kompetensi.

Hal lain yang dirasa membebani siswa selama uji kompetensi yaitu faktor kelelahan. Siswa merasa uji kompetensi yang selama ini dilakukan sangat melelahkan karena selama 5 jam secara terus menerus mereka mengerjakan 5 tugas $(j o b)$. Penelitian ini menemukan model yang bertujuan agar siswa tidak mengalami kelelahan selama uji kompetensi, yaitu Model Tidak Kontinyu.

\section{Mekanisme Pelaksanaan Sistem Uji Kompetensi Model Tidak Kontinyu}

Mekanisme kerja model tidak kontinyu sebagai berikut: 1) Koordinasi asesor ekternal dan internal untuk menyamakan persesi, 2) Membuat dua kelompok, kelompok A dan B, setiap kelompok berisi lima siswa (sesuai jumlah tugas), 3) Kelompok A mengerjakan lima tugas selama satu jam (setiap siswa satu tugas), kemudian istirahat, diganti kelompok B mengerjakan lima tugas selama satu jam, kemudian istirahat, disusul kelompok 1 (satu) mengerjakan lima tugas yang dirotasi. Demikian seterusnya hingga setiap kelompok menyelesaikan lima tugas. Tiap tugas dinilai oleh dua asesor, yaitu asesor internal dan asesor ekternal.

Dengan demikian, setiap kelompok mendapat jeda istirahat satu jam setiap akan mengerjakan ke pos berikutnya. Sistem Rotasi uji kompetensi model tidak kontinyu dapat dilihat pada Gambar 5.

Seluruh peserta $F G D$ setuju dengan mekanisme uji model Tidak Kontinyu, karena memberi peluang siswa istirahat setelah melakukan uji satu materi. Pada model kontinyu siswa mengerjakan lima tugas secara beruntun selama lima jam, ini mengakibatkan siswa kelelahan, sehingga hasilnya tidak optimal. Situasi psikis siswa saat uji kompetensi sangat berbeda jika dibandingkan siswa melakukan kegiatan latihan uji kompetensi. Saat uji kompetensi siswa lebih cepat capek karena situasi yang tegang dan terbebani secara psikis bahwa apa yang mereka kerjakan menjadi tanggung jawabnya sendiri. Siswa akan mendapat beban tambahan berupa tekanan psikis jika kebetulan asesornya kurang bersahabat atau sikapnya menakutkan. Keseluruhan situasi ini yang mengakibatkan siswa cepat lelah sekalipun baru mengerjakan satu tugas. Kondisi fisik yang lelah dan psikis yang tegang yang dialami siswa akhirnya dapat menimbulkan stres. Mekanisme lengkap pelaksanaan uji kompetensi model Tidak Kontinyu dapat dilihat pada Gambar 6. 


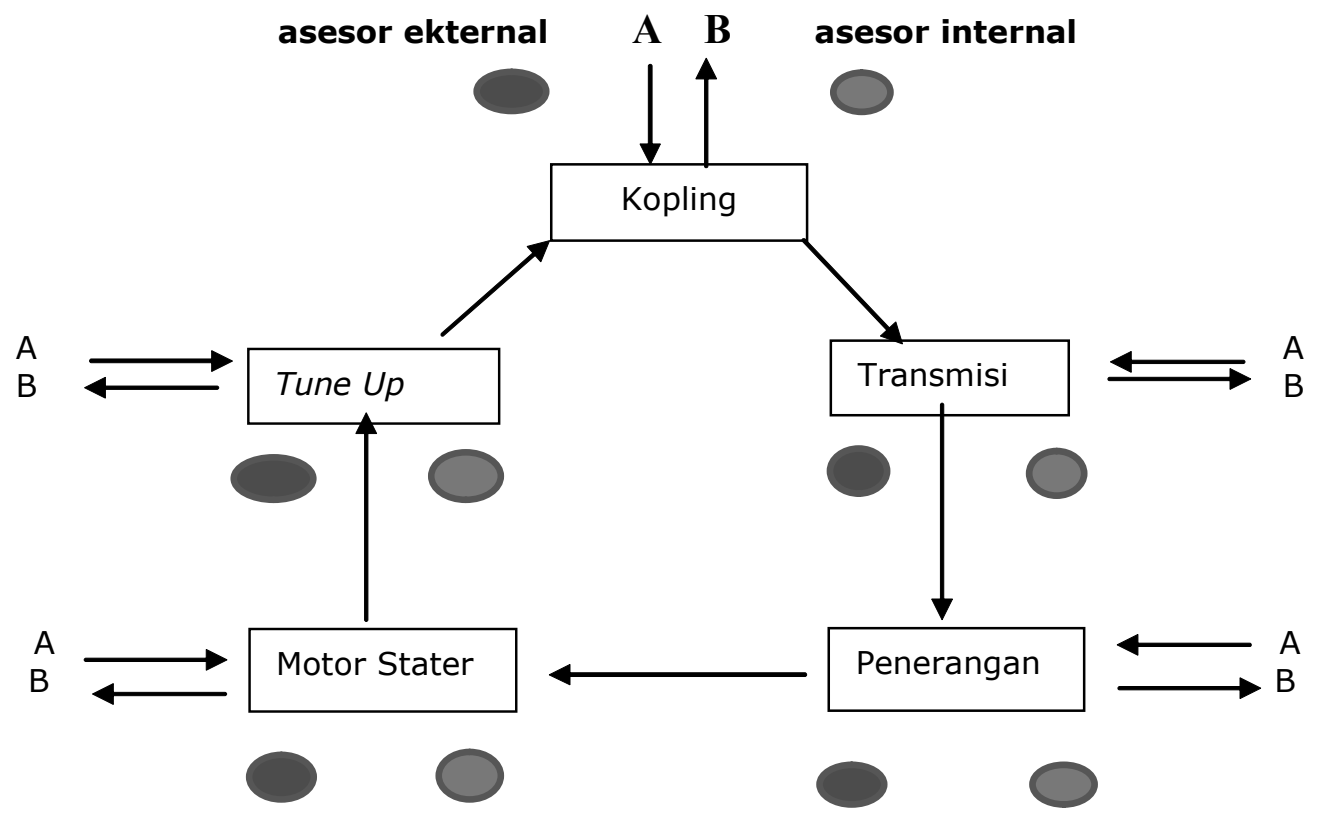

Gambar 5 Rotasi Uji Kompetensi Model Tidak Kontinyu

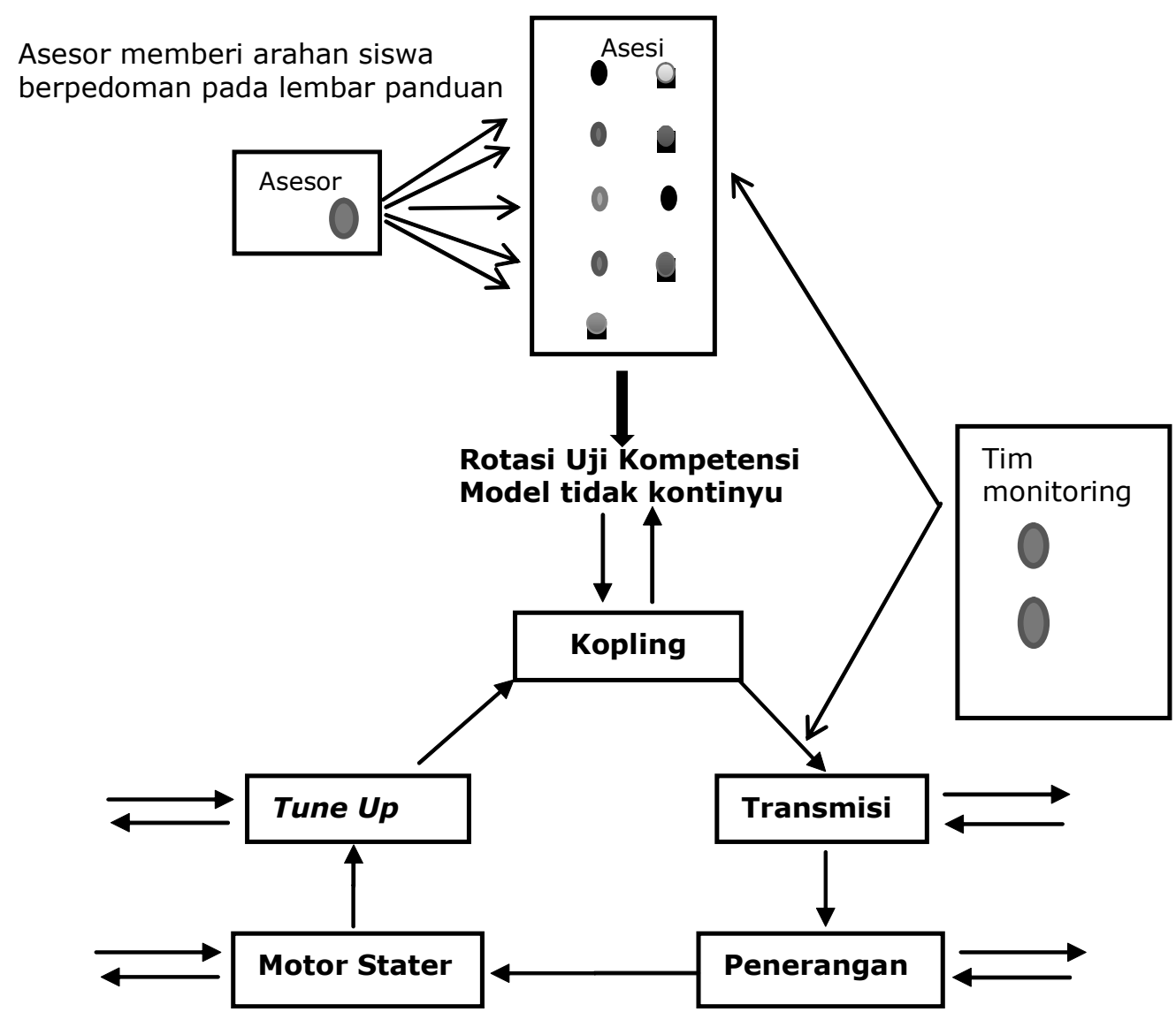

Gambar 6 Sistem Uji Kompetensi Model Tidak Kontinyu 
Langkah awal sebelum ujian kompetensi dimulai yaitu mengumpulkan siswa untuk diberi pengarahan tata tertib pelaksanaan uji kompetensi. Langkah ini juga bertujuan mencairkan suasana antara asesi dan asesor agar siswa tidak takut. Setelah siswa memahami aturan UKK dilanjutkan pelaksanaan uji kompetensi dengan model Tidak Kontinyu. Tim monitoring berperan menjaga agar UKK tidak lepas dengan aturan yang ada.

Model yang didesain tersebut kemudian dimintakan penilaian oleh tim penilai. Hasil penilaian tersebut dijadikan dasar layak tidaknya model diterapkan.

Tabel 2 merupakan isian penilaian model tidak kontinyu yang diisi oleh 10 penilai dari berbagai kepakaran yang relevan dengan tema penelitian. Hasil pendapat tim penilai dimasukan ke dalam Tabel 3 Perolehan skor validasi sistem uji kompetensi model uji kompetensi tidak kontinyu.

Dari Tabel 3 dapat disimpulkan bahwa empat Validator menyatakan sangat layak sekali; empat Validator menyatakan sangat layak, dan

Tabel 2 Penilaian Sistem Uji Kompetensi Model Tidak Kontinyu

Beri tanda ( $v$ ) pada kolom sebelah kanan pernyataan sesuai pendapat Bapak.

Angka 1 = Sangat tidak setuju

Angka 2 = Tidak setuju

Angka 3 = Setuju Angka 4 = Sangat setuju

Angka 5 = Sangat setuju sekali

\begin{tabular}{|c|c|c|c|c|c|c|}
\hline & Pernyataan & 1 & 2 & 3 & 4 & 5 \\
\hline 1 & $\begin{array}{l}\text { Adanya lembar panduan penilaian memperbaiki sikap asesor dalam } \\
\text { menguji. }\end{array}$ & & & & & \\
\hline 2 & $\begin{array}{l}\text { Kalimat di dalam lembar panduan mudah dipahami sehingga kecil } \\
\text { kemungkinan terjadi salah pengertian. }\end{array}$ & & & & & \\
\hline 3 & $\begin{array}{l}\text { Lembar panduan berisi hal-hal yang pokok/praktis, sehingga } \\
\text { mudah dilaksanakan. }\end{array}$ & & & & & \\
\hline 4 & $\begin{array}{l}\text { Tidak sulit bagi asesor melaksanakan sebagaimana ditulis di dalam } \\
\text { lembar panduan. }\end{array}$ & & & & & \\
\hline 5 & $\begin{array}{l}\text { Jika semua asesor bisa melaksanakan seperti yang ada di dalam } \\
\text { lembar panduan, siswa akan nyaman dan senang selama uji } \\
\text { kompetensi. }\end{array}$ & & & & & \\
\hline 6 & $\begin{array}{l}\text { Lembar panduan membantu asesor dalam melaksanakan } \\
\text { penilaian. }\end{array}$ & & & & & \\
\hline 7 & $\begin{array}{l}\text { Penjelasan asesor ke siswa sebelum uji kompetensi dilaksanakan } \\
\text { dapat mencairkan suasana sehingga siswa tidak tegang. }\end{array}$ & & & & & \\
\hline 8 & $\begin{array}{l}\text { Tim monitor yang diterjunkan dari Dinas Pendidikan untuk memo- } \\
\text { nitor pelaksanaan uji kompetensi akan meningkatkan kualitas uji } \\
\text { kompetensi. }\end{array}$ & & & & & \\
\hline 9 & Kehadiran tim monitor meningkatkan disiplin asesi dan asesor. & & & & & \\
\hline 10 & Kehadiran tim monitor menurunkan kecurangan uji kompetnsi. & & & & & \\
\hline 11 & $\begin{array}{l}\text { Keterbatasan petugas tim monitor di Dinas Pendi-dikan, maka } \\
\text { diambil dari mahasiswa yang sedang menulis skripsi, yang } \\
\text { sebelumnya diberi pembekalan. }\end{array}$ & & & & & \\
\hline 12 & $\begin{array}{l}\text { Uji kompetensi dengan model "tidak kontinyu" membantu siswa } \\
\text { tidak kelelahan. }\end{array}$ & & & & & \\
\hline 13 & $\begin{array}{l}\text { Penerapan model uji "tidak kontinyu" dapat meningkatkan } \\
\text { perolehan skor uji kompetensi. }\end{array}$ & & & & & \\
\hline 14 & Model uji "tidak kontinyu" mudah dilaksanakan. & & & & & \\
\hline
\end{tabular}

\section{Catatan}

Skor Maksimum tiap responden: $5 \times 14=70$

Skor Minimum tiap responden: $1 \times 14=14$ 
Tabel 3 Perolehan Skor Validasi Sistem Uji Kompetensi Model Uji Kompetensi Tidak Kontinyu

\begin{tabular}{|l|c|c|l|}
\hline No & Nama Penilai & Skor & \multicolumn{1}{|c|}{ No Keterangan } \\
\hline 1 & A & 61 & Sangat layak sekali \\
\hline 2 & B & 65 & Sangat layak sekali \\
\hline 3 & C & 67 & Sangat layak sekali \\
\hline 4 & D & 53 & Sangat layak \\
\hline 5 & E & 57 & Sangat layak \\
\hline 6 & F & 45 & Layak \\
\hline 7 & G & 38 & Layak \\
\hline 8 & H & 58 & Sangat layak \\
\hline 9 & I & 64 & Sangat layak sekali \\
\hline 10 & J & 50 & Sangat layak \\
\hline
\end{tabular}

Kriteria skor : $14-24$ : Sangat tidak layak diterapkan

25 - 35 : Tidak layak diterapkan

$36-46$ : Layak diterapkan

$47-58$ : Sangat layak diterapkan

59 - 70 : Sangat layak sekali diterapkan

dua Validator menyatakan layak. Dengan demikian dapat disimpulkan bahwa model sangat layak diterapkan untuk memperbaiki model lama, yaitu model Kontinyu.

Dua fenomena model, yaitu model kontinyu dan model tidak kontinyu telah dijelaskan di atas. Berdasarkan faktor kelelahan, model kontinyu sangat melelahkan karena tanpa ada jeda istirahat.

Hal ini tidak sejalan dengan pendapat Murrel (1965) yang merumuskan metoda untuk menentukan waktu istirahat sebagai kompensasi dari pekerjaan fisik. Oleh karena itu model tidak kontinyu akan memberi manfaat asesi dalam melaksanakan uji kompetensi dengan ada waktu jeda istirahat.

\section{Simpulan dan Saran Simpulan}

Mengkondisikan suasana uji yang rilek bebas dari perasan mencekam dapat meningkatkan performa siswa dalam uji kompetensi. Panduan asesor produk penelitian yang berisi tentang bagaimana performa asesor sebelum dan selama proses uji kompetensi diharap dapat memberi kontribusi pembentukan kesamaan perilaku asesor dalam menjalankan tugas sebagai asesor uji kompetensi. Kelelahan siswa dalam mengerjakan 5 tugas secara kontinyu diharapkan dapat diatasi dengan mengunakan Model Tidak Kontinyu. Model Tidak Kontinyu, yaitu model uji kompetensi yang memberi jeda istirahat tiap selesai mengerjakan satu tugas dirasa signifikan membantu siswa mengerjakan tugas lebih baik. Penelitian ini sebagai studi awal memukan model yang perlu dilanjutkan pada penelitian berikutnya berupa uji aplikasi model. 


\section{Saran}

Dua permasalahan yang diajukan pemecahanya dalam penelitian ini. Permasalahan pertama, yaitu perilaku asesor yang membuat siswa tertekan. Sebelum uji kompetensi asesor sebaiknya masuk ke dalam sistem siswa. Asesor menunjukan ke siswa bahwa dirinya bukanlah penguji yang menentukan lulus tidaknya siswa. Asesor hanya ingin mengetahui aspek keterampilan, kognisi, dan afeksi siswa dalam penguasaan otomotif sebagai calon mekanik otomotif di dunia kerja. Asesor memperkenalkan diri ke siswa dan membangun sistem pergaulan yang menyenangkan, sehingga siswa tidak merasa takut saat uji kompetensi. Bangkitkan semangat siswa dalam mengerjakan tugas. Tugas tidak boleh dikerjakan terburu-buru, tetapi harus dikerjakan sesuai prosedur yang ada. Upayakan hubungan antara asesor dengan siswa menjadi hubungan secara kekeluargaan. Permasalahan kedua, yaitu faktor kelelahan siswa dalam mengerjakan lima tugas yang beruntun. Model tidak kontinyu dengan memberi celah istirahat setiap satu pekerjaan merupakan solusi yang tepat. Saat siswa beristirahat asesor dapat memberi semangat agar siswa mempersiapkan materi yang akan datang dengan cara melihat uji kompetensi temennya. Kecuali itu asesor juga bisa memberi arahan agar selama istirahat siswa dapat menggunakan waktu untuk membaca materi yang akan diujikan. Kecuali itu waktu istirahat dapat digunakan untuk sharing pengalaman sesama teman yang akan diuji dan jika dirasa sudah siap dapat digunakan untuk rileks sambil menunggu uji berikunya. Dengan demikian siswa akan tetap dalam kondisi fresh dan siap melaksanakan tugas berikutnya.

\section{Pustaka Acuan}

Artikelbaden. 2012. http://artikelbaden.blogspot.com/2012/12/Strategi-manajemen-stresskerja. html. Diakses tanggal 9 Juli 2014.

Bartley \& Chute.1982. http://batikyogya.wordpress.com/. Diakses tanggal 9 Juli 2014.

Borg, W. R. \& Gall, M. D. 1983. Educational Research: An Introduction. New York and London: Longman.

Direktorat Pembinaan Sekolah Menengah Kejuruan. 2013. Pedoman Penyelenggaraan Uji Kompetensi Keahlian (UKK) SMK Tahun Pelajaran 2012/ 2013, Jakarta.

Ennis, M. R. 2008. Competency Model: A review of the Literature and The Role of Employment and Training Administration (ETA). Pilot and Demonstration Team Division of Research and Evaluation Ofice of Policy Development and Research Employment and Training Administration U.S. Departement of Labour.

Finch, R. C., \& John, R. C. 1979. Curriculum Development in Vocational and Technical Education. Boston: Allyn and Bacon Inc.

Indonesia Australia Partnership for Skil Development, Automotive Project. 2001. Program Pelatihan Penilaian Tempat Kerja. Jakarta, Indonesia.

Kurniawati, F.N.I., \& Astuti, Y.D. 2008. "Hubungan Antara Prokrastinasi dan Stres Kerja pada Karyawan Pt. Armada FinanceMagelang" Laporan Penelitian. Program Studi Psikologi Fakultas Psikologi dan IImu Sosial Budaya Universitas Islam Indonesia, Yogyakarta.

Lazerzon, M., \& Grubb,W.N. 1974. American education and vocationalism: A documentary history1870-1970. New York: Teachers College Pres. 
Mauludi. M. N. 2010. Faktor-faktor yang Berhubungan Dengan Kelelahan Pada Pekerja di Proses Produksi Kantong Semen Paper Bag Division PT Indocement tungal prakarsa tbk. Citeureup-Bogor, Skripsi.

Miuzzudin, A. 2013. Hubungan Antara Kelelahan KerjaDengan Produktivitas Kerja Pada Tenaga Kerja Bagian Tenundi PT. Alkatex Tegal (Skripsi) tidak dipublikasikan.

Modul Pengukuran Performasi Kerja dalam http://www. dhimaskasep. files.wordpress.com/2008/ 05/modul-2.doc. Diakses tanggal10 Juli 2014.

Peraturan Pemerintah Republik Indonesia Nomor 19 Tahun 2005 tentang Standar Nasional Pendidikan.

Rochman. T., Astuti,D., \& Miftahudin. 2012. Usulan Perbaikan Terhadap Aktivitas Penurunan Pasir Di Depo Pasir Makmur Menggunakan Pendekatan Postur Kerja Dan Assessment Terhadap Fisiologi Kerja (Studi Kasus: Depo Pasir Makmur, Surakarta) . Prosiding Seminar Nasional Aplikasi Sains \& Teknologi (SNAST) Periode IIIISSN: 1979-911X Yogyakarta,3 November 2012

Subandowo, M. 2009. Hubungan antara Motivasi, Sikap dan Kelelahan Non Fisik dengan Produktivitas Kerja para Penguasaha Kecil di Jawa Timur, Indonesia. Jurnal Pendidikan Sains Sosial dan Kemanusian "Sosio Humanika", 2 (2) November 2009.

Surat Edaran Dirjen Mandikdasmen Depdiknas Nomor 351/C.C5/MN/2007 tanggal 26 Januari 2007 perihal Pelaksanaan Uji Kompetensi Keahlian (UUK) Bagi Siswa SMK pada Tahun Pelajaran 2006/2007.

Syamwil, R. 2010. Pengembangan Model Muatan Pravokasional dan Pembelajaran Dalam Kurikulum SMP/MTs di Sentra Industri Batik. Disertasi Doktor. Tidak diterbitkan, Program Pascasarjana Universitas Negeri Yogyakarta. Yogyakarta.

Samsudi, Budiyono, A., Supraptono, E., Wijaya, B.R., \& Widayat, W. 2007. Pelaksanaan Uji Kompetensi Keahlian Dalam Rangka Ujian Nasional SMK Laporan Penelitian. Kerjasama Universitas Negeri Semarang dengan Direktorat Pembinaan SMK. Departemen Pendidikan Nasional.

Trinidad \& Tobago. 2005. Hemispheric Project School Management and Educational

Certification for Development and Accreditation of Key and Basic Labour Competencies at The Upper Secondary Level. (Project SED/AICD/AE-).

Undang-Undang Republik Indonesia Nomor 20 Tahun 2003 tentang Sistem Pendidikan Nasional. Jakarta: Penerbit Sinar Grafika.

Widyarni, N. 2009. Seri Psikologi: Kunci Pengembangan Diri. Jakarta: PT Elex Media Komputindo Kelompok Gramedia. 
Jurnal Pendidikan dan Kebudayaan, Vol. 21, Nomor 1, April 2015 